\title{
Utilization of Decane, Heptane, Petrol and Hexadecane by Fungi Isolated from Engine Oil Contaminated Soil in Ilorin
}

\author{
*ADETITUN, DO; SULAIMAN, RD; OGUNTOYE, MB
}

\author{
Department of Microbiology, Faculty of Life Sciences, University of Ilorin, P.M.B. 1515 Ilorin, Kwara State, Nigeria. \\ *Corresponding Author Email: adetitun.do@unilorin.edu.ng; Tel: +2348036910988
}

\begin{abstract}
Fungi with hydrocarbon degrading capabilities were isolated from spent engine oil contaminated soil obtained from five automobile workshops in Ilorin, Nigeria. Preliminary analysis of degradation of the hydrocarbon was performed using Mineral Salts Medium (MSM). The organisms identified include Aspergillus sp., Blastomyces dermatitidis, Cladophialophora bantiana, Mucor circinelloides, Phaeoacremonium parasiticum, Rhizopus arrhizus, Neosartorya fischeri, Cladosporium $\mathrm{sp}$. and Microsporium furrigenum. They were identified based on their morphological and cultural characteristics. Findings from this study showed Aspergillus sp. and Mucor circinelloides were able to degrade hexadecane, heptane, decane and petrol as sole carbon and energy source within 20days. Hydrocarbon utilization rate ranged from 0.020 to 0.284 for heptane, 0.0120 to 0.4965 for decane, 0.079 to 0.340 for hexadecane and 0.023 to 0.268 for petrol. Measurement of optical density and $\mathrm{pH}$ was carried to determine hydrocarbon degradation by fungi. The results of this study shows that fungi can play important roles in the effective clean-up of hydrocarbon contaminated soils thereby making them environmentally friendly.
\end{abstract}

DOI: https://dx.doi.org/10.4314/jasem.v23i9.11

Copyright: Copyright $(C 2019$ Adetitun et al. This is an open access article distributed under the Creative Commons Attribution License (CCL), which permits unrestricted use, distribution, and reproduction in any medium, provided the original work is properly cited.

Dates: Received: 30 August 2019; Revised: 25 September 2019; 28 September 2019

Keywords: Engine Oil, Fungi, Soil, hydrocarbons.

Development and technological advancements have characterized the production, distribution and use of petroleum products. Anthropogenic activities such as industrial and municipal effluent discharge, activities of offshore and onshore petroleum industries as well as accidental spills cause pollution (Sajna et al., 2015). Petroleum products like diesel, engine oil, kerosene and petrol are used daily in automobile workshops. Most auto-mechanic workshops in many developing countries such as Nigeria lack regulations and standards to guide their operations and disposal of used engine oil and other petroleum products (Kpakpavi, 2015). The careless disposal of these products results in pollution of the soil and aquifer (Onifade et al., 2007) and pollution of the soil by hydrocarbons is hazardous to the ecosystem as it results in depletion of plant nutrients, bioaccumulation of pollutants in plants as well as bioaccumulation and biomagnification in animal tissues thus; leading to acute or chronic health effects, mutations and consequently, death (Ekhaise and Nkwelle, 2011; Oluwajiose et al., 2105; Nkwoada et al., 2018). Globally, the spills from crude oil and removal of hydrocarbons from the environment have posed a great challenge, but the use of microorganisms in bioremediation of polluted sites has become an efficient technique to ameliorate pollution (Karthika et al., 2017). Omotayo et al. (2012) established that the success of oil spill clean-up is dependent on the presence of microorganisms with appropriate metabolic abilities. However, factors such as adsorption rates and low solubility have restricted the utilization rates of hydrocarbons by microorganisms (Millioli et al., 2009). Soil is a major component of the ecosystem and also an important carbon sink in the environment (Davidson et al., 2006). Soil is the habitat for variety of organisms, including fungi, bacteria, protozoa, viruses, insects, nematodes, worms, and many other animals. These complex biological communities contribute to the formation, maintenance, and in some situations, the degradation and disappearance of soils (Prescott et al., 2005). Microorganisms such as fungi are extremely diverse and can adapt to survive in harsh environments and are capable of breaking down many complex molecules by adaptation of their degradative enzyme system (Boonchan et al., 2000). Fungi are abundantly found in a host of environments, and are independent, parasitic or mutually beneficial in existence. Fungi are vital in maintaining the proper functioning of the ecosystem by decaying dead matter and releasing vital nutrients in the soil and atmosphere (Natasha, 2019). They are producers of extracellular enzymes that make them capable of metabolizing pollutants. These 
contaminated sites are a reliable niche for the assimilation of substrates which they utilize as carbon source (Ojo, 2006). Many studies have shown the role of fungi in the biodegradation of various petroleum products and the most common biodegraders are of the genera: Aspergillus, Candida, Mucor, Penicillium, Geotrichum, Alternaria, Rhizopus etc (Husaini et al., 2008). This work aims to establish the ability of fungi isolated from soil contaminated with spent engine oil to utilize hydrocarbons.

\section{MATERIALS AND METHODS}

Collection of Soil Samples: Samples contaminated with spent engine oil were collected from five (5) automobile workshops located in Tanke, Ilorin. The samples were collected in the morning before the workers get to their workshop.

Sample Bioassay: Preparation of media was carried out in accordance with the directions provided by the manufacturer. All media along with Petri dishes, pipettes, glassware were sterilized in an autoclave at $121^{\circ} \mathrm{C}$ for 15 minutes. Pouring of media into plates as well as other microbiological processes was carried out aseptically. For preliminary study of engine oil degrading fungi, time course degradation of the hydrocarbon was performed using mineral salts agar medium described by Vecchioli et al., (1990). The composition of the mineral salts medium used was $\mathrm{MgSO}_{4} .7 \mathrm{H}_{2} \mathrm{O}(0.2 \mathrm{~g}), \mathrm{KNO}_{3}(0.3 \mathrm{~g}), \mathrm{KH}_{2} \mathrm{PO}_{4}(0.5 \mathrm{~g})$, $\mathrm{Na}_{2} \mathrm{HPO}_{4}(1.4 \mathrm{~g}),\left(\mathrm{NH}_{4}\right)_{2} \mathrm{SO}_{4}(1.0 \mathrm{~g})$, Distilled water (1L). The MSM bottles were inoculated in 36 bottles with 18 controls: 12 bottles for each hydrocarbon and 6 controls for each hydrocarbon. The chemicals were measured using aluminum foil on a weighing balance and dispensed into an Erlenmeyer flask and $250 \mathrm{ml}$ of water was poured into the flask and swirled till completely dissolved. It is then poured into a washed 1 litre keg and $70 \mathrm{ml}$ of water is added and shaken. $20 \mathrm{ml}$ is dispensed into each falcon's bottle and sterilized by autoclaving at $121^{\circ} \mathrm{c}$ for $15 \mathrm{mins}$ and wait to cool.

Isolation of Fungi from Diesel Contaminated Soil: Exactly 5 grams of Saboraud Dextrose Agar (SDA) was measured on a weighing balance and dispensed into an Erlenmeyer flask and $125 \mathrm{~g}$ of water was dispensed into it and swirled till no visible lumps. It was filtered into a falcon's bottle, covered and sterilized by autoclaving at $121^{\circ} \mathrm{C}$ for 15 mins. The enumeration of fungi was done using serial dilution plating method. $1 \mathrm{~g}$ of soil samples from each site was dispensed in a $9 \mathrm{ml}$ sterile distilled water and labeled respectively. It was then diluted tenfold up to $10^{-5}$. Plating was done at a serial dilution of $10^{-5}$ and $10^{-4}$ respectively. Streptomycin was added into the media to inhibit bacteria growth, poured into the Petri dish and swirled. Incubation was carried out at room temperature for three (3) days.

Characterization and Identification of Fungal Isolates: The fungi that grew on the media were considered as degraders of hydrocarbons. After the third (3) day, they were aseptically smeared on a glass slide, stained with lactophenol blue and covered with a cover slip and examined accordingly. The isolates were identified according to their macroscopic and microscopic characteristics based on their form, elevation, margin, size, colour, opacity and surface as reported by (Aneja, 2007; Fawole and Oso, 2007).

Evaluation of the ability of fungi to degrade hydrocarbon - heptane, decane, hexadecane and petrol: Measurement of Optical Density: Mineral Salts Medium (MSM) prepared for the fungal isolates contained $0.5 \mathrm{~g} / 1 \quad \mathrm{KH}_{2} \mathrm{PO}_{4}, 1.4 \mathrm{~g} / \mathrm{l} \quad \mathrm{Na}_{2} \mathrm{HPO}_{4}, 0.2 \mathrm{~g} / \mathrm{l}$ $\mathrm{MgSO}_{4} .7 \mathrm{H}_{2} \mathrm{O}, 0.3 \mathrm{~g} / 1 \mathrm{KNO}_{3}, 1.0 \mathrm{~g} / 1\left(\mathrm{NH}_{4}\right)_{2} \mathrm{SO}_{4} .20 \mathrm{ml}$ of the Mineral Salts Broth (MSB) was measured inside 16 reaction bottles. 12 of the reaction bottles were divided into 2 for day $1,4,8,12,16$ and 20 respectively while the remaining 4 reaction bottles were used as control. All the reaction bottles containing the Mineral Salts Broth were sterilized in an autoclave at $121^{\circ} \mathrm{C}$ for 15 minutes. $26 \mu 1$ of hexadecane was measured inside $20 \mathrm{ml}$ of MSB and the measurement of heptane was gotten from this calculation according to Zampolli et al. (2014): The micropipette was set to measure $26 \mu 1$ of hexadecane and was put into sterile Mineral Salts Medium (MSM). The fungi isolate was added into the $20 \mathrm{ml}$ mineral salts medium and incubated for three days. The plates were then incubated at $25^{\circ} \mathrm{C}$. The optical density (OD) was monitored and recorded every four (4) days for twenty (20) days. The measurement of OD was done using a spectrophotometer at a wavelength $600 \mathrm{~nm}$ according to (Kumar and Manjunath, 2015). This procedure was repeated for heptane $(33 \mu \mathrm{l})$, decane $(27 \mu \mathrm{l})$ and petrol $(26 \mu \mathrm{l})$ all of which were added to $20 \mathrm{ml}$ of Mineral Salts Medium respectively.

Measurement of $\mathrm{pH}$ : Growth of Aspergillus sp. on spent engine oil substrate was carried out by the inoculation of each of the fungal cultures into a $250 \mathrm{ml}$ Erlenmeyer flask as described by Oboh et al. (2006). The isolate was added and left for 3 days. $1.5 \mathrm{ml}$ of the isolate was supplemented into each falcon bottle as a carbon source. The falcon tubes were tightly closed and incubated at room temperature and readings taken at an interval of 4 days for 20 days. The $\mathrm{pH}$ meter used was calibrated with buffer of $\mathrm{pH} 7.0$ before use and readings from the $\mathrm{pH}$ meter were noted and recorded accordingly. 


\section{RESULTS AND DISCUSSION}

A total of sixteen (16) fungi were isolated in this study and they were identified based on their morphological and cultural characteristics. However, nine (9) of the fungi were identified due to their appearances on different plates. The organisms identified include Aspergillus sp., Blastomyces dermatitidis, Cladophialophora bantiana, Mucor circinelloides, Phaeoacremonium parasiticum, Rhizopus arrhizus, Neosartorya fischeri, Cladosporium sp. and Microsporium furrigenum which agrees with those reported in the researches of Obire and Anyanwu, (2009) and Romeo et al. (2010). Fungi are capable of biodegradation due to their resistance to hydrocarbons. An example of a good fungal biodegrader is Aspergillus sp. which is capable of degrading a wide range of hydrocarbon pollutants. The isolation of these fungi from the contaminated sites may be as a result of their ability to synthesize enzymes that enable them to utilize the spent engine oil in soil thereby causing (Zhang et al., 2016a). Table 1 gives the characteristics of the fungal isolates that could degrade the spent engine oil and most of them were found to be molds.

Table 1: Characterization of fungal isolates

\begin{tabular}{|c|c|c|}
\hline Cultural Characteristics & Microscopic Characteristics & Probable Isolates \\
\hline $\begin{array}{l}\text { White/cream colour non-sporulating } \\
\text { colonies }\end{array}$ & $\begin{array}{l}\text { Large, yeast forms, single bud attached by a } \\
\text { broad base }\end{array}$ & lBastomyces dermatitidis \\
\hline $\begin{array}{l}\text { Black to green colour olive to purple- } \\
\text { brown reverse side }\end{array}$ & $\begin{array}{l}\text { Conidia heads are short, columnar, Hyphae } \\
\text { was small with distinct cross-septa }\end{array}$ & Aspergillus sp. \\
\hline $\begin{array}{l}\text { White to pale yellow colour colony with } \\
\text { good growth }\end{array}$ & Conidia heads are short, columnar & Neosartorya fischeri \\
\hline $\begin{array}{l}\text { Moderate growth colony, grey- suede to } \\
\text { floccose colour }\end{array}$ & Conidia sparsely branched and very long & Cladophialophora bantiana \\
\hline Waxy surface colony and slow growing & $\begin{array}{l}\text { Irregular branching hyphae with prominent } \\
\text { cross walls }\end{array}$ & Microsporum furrigenum \\
\hline Brown/grey, floccose slow growing colony & $\begin{array}{l}\text { Vegetative hyphae, Conidiospores and } \\
\text { condia pigmented }\end{array}$ & Cladosporium $\mathrm{sp}$ \\
\hline Whitish-grey colony & Conidia, phialide are funnel-shaped & Phaeoacremonium parasiticum \\
\hline $\begin{array}{l}\text { White cotton to brownish grey blackish- } \\
\text { grey color }\end{array}$ & Non-septate sporangiospores & Rhizopus arrhizus \\
\hline $\begin{array}{l}\text { Floccose, pale greyish-brown colour with } \\
\text { poor growth }\end{array}$ & $\begin{array}{l}\text { Branched sporangiospores bearing brown- } \\
\text { like sporangia }\end{array}$ & Mucor circinelloides \\
\hline
\end{tabular}

The degradation of petroleum and its derivatives depend on the concentration and composition of the petroleum hydrocarbon (PAH), abiotic factors as well as microbial biomass in the soil. These conditions make microorganisms respond to pollution (Atagana et al., 2006). Fungi are not dependent on soluble, organic compounds for nutrition hence; they are capable of secreting different enzymes that get attached to polymeric substances (Harms et al., 2011). The work of Uzoamaka et al. (2009) authenticated that fungi isolates obtained from oil contaminated soils had biodegradation abilities. To correlate this, hydrocarbon utilizing fungi which included Aspergillus fumigatus, Aspergillus niger, Penicillium xingiiangense, Mucor racemosus were isolated from polluted soils in the study of Edna et al. (2016) however, Aspergillus sp. and Penicillium xingjiangense were found to be more effective in hydrocarbon degradation. Figure 1 is descriptive of the occurrences of fungi isolates at the different sample sites.

$\mathrm{pH}$ and Optical density determination: Soil $\mathrm{pH}$ is crucial for enzymatic activities. The $\mathrm{pH}$ of soil affects substrate availability. Extreme $\mathrm{pH}$ can denature enzymatic structure and prevent the enzyme from acting on available substrates in the soil (Zhang et al., 2016b). Figure 2 shows the $\mathrm{pH}$ values of the Mineral Salts Medium in the engine oil degraded samples. From the chart, the highest $\mathrm{pH}$ value obtained was 6.85 while the lowest was 5.62 and this shows that hydrocarbons are substances that partially dissociates into ions when dissolved in a solvent (i.e. they are weak acids) as stated by Jönsson et al. (2013).

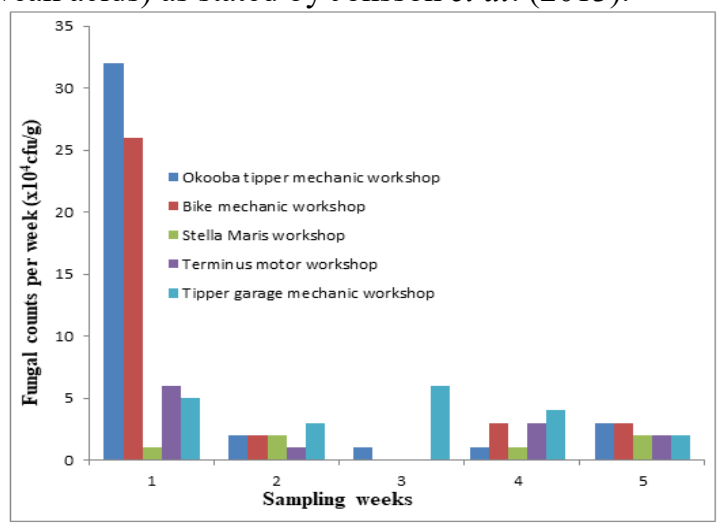

Fig 1: Total fungal counts 


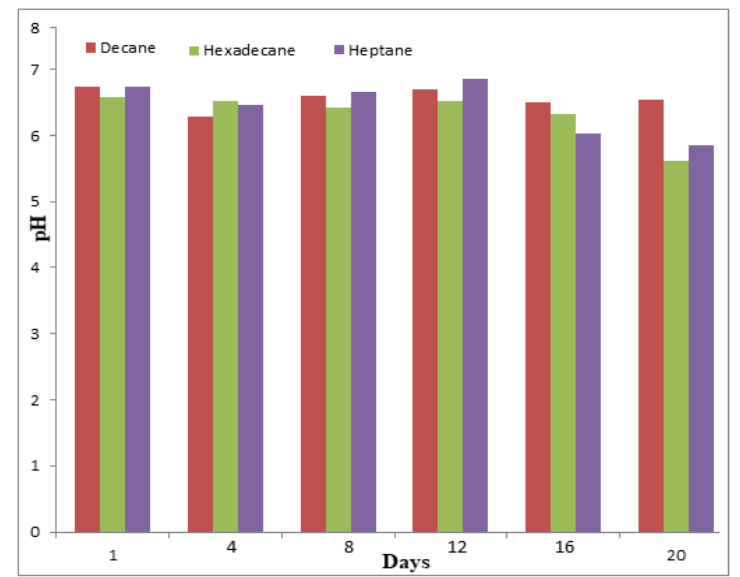

Fig 2: $\mathrm{pH}$ values of the Mineral Salts Medium in the engine oil degraded samples.

In Figure 3, growth configuration showed that there was slight significant difference in microbial growth of Aspergillus niger as evidenced in the decline on the growth curve for Day 2. Bagherzadeh-Namazi et al. (2008) reported that peak reduction is a strong evidence for degradation. The slow degradation showed from Day 2 to Day 4 by the optical density readings is probably due to climatic conditions, temperature and nutrient availability which are the major factors affecting biodegradation (Xiaoxu and Joel, 2019). Utilization of hexadecane, heptane, decane and protein by Mucor circinelloides in Figure 4 shows a higher nutrient uptake. The figure shows a value decrease on Day 5 and peak increase on Day 6 for petrol, decane and heptanes respectively meaning that Mucor circinelloides continued to utilize the hydrocarbon present in the mineral salts medium depicting availability of nutrients. Generally, petroleum hydrocarbons in soil affects moisture holding capacity, soil permeability, microbial growth, physicochemical properties of soil and all these ultimately sum up in the damage of the environment (Ezeigbo et al., 2013; Zhang et al., 2018).

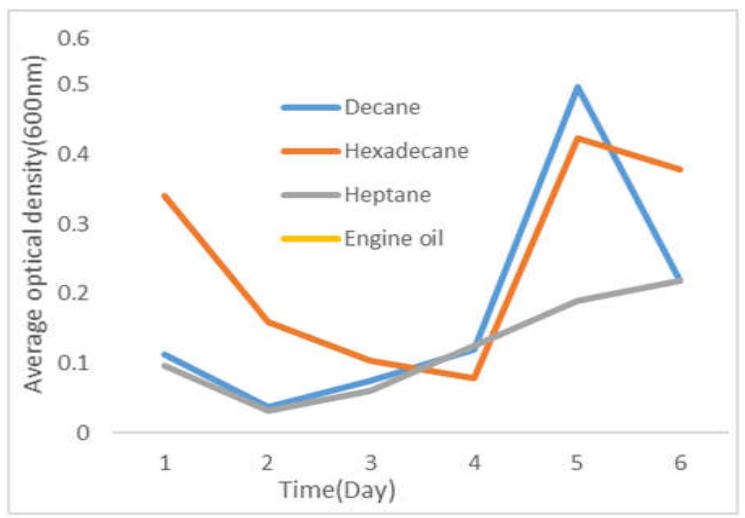

Fig 3: Optical density measurement of Aspergillus sp.

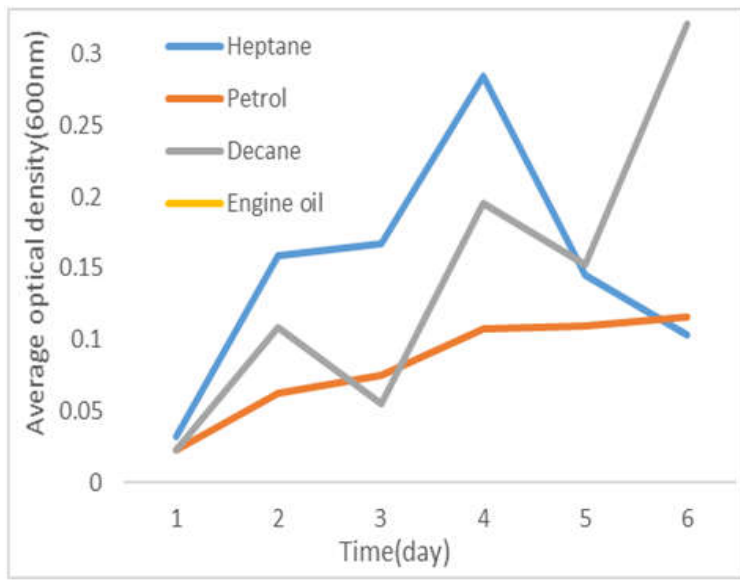

Fig 4: Optical density measurement of Mucor circinelloides

Microbial degradation of crude oil is often shown to occur by attack on alkanes or light aromatic fractions, while the higher molecular weight aromatics, resins and asphaltenes are considered recalcitrant. Crude oil, particularly the aromatic fraction is acutely lethal to agricultural soils at varying concentrations. Affected soils lose their fertility and become unproductive but within a few years, crude oil contaminated soils return to full productivity when appropriate clean-up techniques are used (Kisic et al., 2009; Parlak and Parlak, 2011).

Conclusion: Contamination of the soil by petroleum products alter soil properties and result in a significant level of toxicity in the soil. Thus, use of microorganisms as bioremedial tools has become a highly recognized technique in tackling environmental pollution caused by oil spills hence; this study buttresses the exploration and utilization of fungi species for the efficient bioremediation of petroleum and its derivatives in the environment.

\section{REFERENCES}

Aneja, KR (2007). Experiments in Microbiology, Plant pathology and Biotechnology. $4^{\text {th }}$ ed. New Age International Publication Limited, New Delhi. pp. 145-156.

Atagana, HI; Haynes, RJ; Wallis, FW (2006). Fungal bioremediation of creosote-contaminated soil: A laboratory scale bioremediation study using indigenous soil fungi. Water, Air and Soil Poll. 172:201-219.

Bagherzadeh-Namazi, A; Shojaosadati, SA; Hasheemi-Najafabadi, S (2005). Biodegradation of used engine oil using mixed and isolated cultures. Intl Jour of Environ Res. 2:431-440. 
Boonchan, S; Britz, MC; Stanley, GA (2000). Degradation and Mineralization of high Molecular Weight Polycyclic Aromatic Hydrocarbons by defined Fungal-bacterial Co cultures. App Environ Microb. 66 (3): 1007 1019.

Davidson, EA; Janssens, IA (2006). "Temperature sensitivity of soil carbon decomposition and feedbacks to climate change". Nature. 440: 16573.

Edna, I.C; Nwando, MO; Amechi, SN (2016). Hydrocarbon degradation potentials of fungi associated with oil-contaminated soil from selected mechanic workshops in Awka, Anambra State, Nigeria. Front in Environ Microb. 2(6):3844.

Ekhaise, FO; Nkwelle, J (2011). Microbiological and physiochemical analysis of oil contaminated soil from major motor mechanic workshops in Benin City Metropolis, Edo State, Nigeria. Journ of App Sci and Environ Mangt. 15(4):597-600.

Ezeigbo, OR; Ukpabi, CF; Abel-Anyebe, O; OkikeOsisiogu, FU; Ike-Amadi, CA; Agomoh, NG (2013). Physico-chemical properties of soil contaminated with refined petroleum oil in Eluama Community, Abia State, Nigeria. Int Journ of Scien Res and Managt. 1(8):405-413.

Fawole, MO; Oso, BA (2007). Laboratory Manual of Microbiology, Spectrum Books Limited, Ibadan, Nigeria. pp.127.

Harms, H; Schlosser, D; Wick, LY (2011). Untapped Potential: Exploiting fungi in bioremediation of hazardous chemicals. Nat Rev Microb. 9(3):177192.

Husaini, A; Roslan, HA; Hii, KSY; Ang, CH (2008). Biodegradation of aliphatic hydrocarbon by indigenous fungi isolated from used motor oil contaminated sites. World Journ of Microb and Biot. 24:2789-2797.

Jönsson, LJ; Alriksson, B; Nilvebrant, NO (2013). Bioconversion of lignocelluloses: Inhibitors and detoxification. Biotech for Bio. 6:16.

Karthika, R; Archaya, S; Nandhini, S; Gopinath, LR; Bhuvaneswari, R (2017). Isolation and identification of effective hydrocarbon degrading bacteria from diesel polluted soil. Journ of Biotech and Bioch. 3(3):60-63.
Kisic, I; Mesic, M; Basic, F; Brkic, V; Mesic, M; Durn, G; Zgorelec, Z; Bertovic, L (2009). The effect of drilling fluids and crude oil on some chemical characteristics of soil and crops. Geoderma. 149 (4): 209-216.

Kpakpavi, M (2015). Use oil storage and disposal practices in automobile repair garages in Ghana. Intern Journ of Sc, Tech and Soc. 3(4): 191-201.

Kumar, GA; Manjunath, G (2015). Biodegradation of complex hydrocarbons in spent engine oil by novel bacterial consortium isolated from deep sea sediment. Biores Tech. 170(2014): 556-564.

Millioli, VS; Servulol, ELC; Sobrald, LGS; de Carvalho, DD (2009). Bioremediation of crude oil-bearing soil: Evaluating the effect of rhamnolipid addition to soil toxicity and crude oil biodegradation efficiency. Glob NEST Journ. 11:181-188.

Natasha, G (2019). Common types of fungi found in soil. Sc and Educat. (4): 1-4.

Nkwoada, AU; Alisa, CO; Amakom, CM (2018). Pollution in Nigerian auto-mechanic villages: A Review: Environ Sc, Tox and Food Tech. 12 (7): 43-54.

Obire, O; Anyanwu, EC (2009). Impacts of various concentrations of crude oil on fungal populations of soil. Intern. J. Environ. Sci.Tech. 6:211-218.

Oboh, BO; Ilori, MO; Akinyemi, JO; Adebusoye, SA (2006). Hydrocarbon degrading potentials of Bacteria isolated from a Nigerian Bitumen (Tarsand) deposit. Nat Sc. 4(3) 51-57.

Ojo, OA (2006). Petroleum-hydrocarbon utilization by native bacterial population from a wastewater canal in Southwest Nigeria. Afr. J. Biotech. 5:333337.

Oluwajiose, O; Akinsete, S; Ana, G; Omishakin, A (2015). Soil contamination by refined crude oil using Lumbricus terrestris as toxicity indicator at a petroleum product depot, Ibadan, Nigeria. Cur. J. Appl. Sci. Tech. 9(1): 37-46.

Omotayo, AE; Ojo, OY; Amund, OO (2012). Crude oil degradation by microorganisms in soil composts. Res J. Micro. 7(4):209-218. 
Onifade, AK; Abubakar, FA; Ekundayo, FO (2007). Bioremediation of oil-polluted soil in the Niger Delta area of Nigeria using enhanced natural attenuation. Res. J. Animal. Sci. 2:498-504.

Parlak, M; Parlak, AÖ (2011). Effect of soil compaction on root growth and nutrient uptake of forage crops. J. Food, Agric. Environ. 9(3): 275278 .

Prescott, LM; Harley, JP; Klein, FA (2005). Microbiology Sixth Edition Mc Graw Hill Publishers. pp. 383-384.

Romeo, MC; Urrutia, MI; Reinoso, HE; Kiernan, MM (2010). Benzo(a)pyrene degradation by soil filamentous fungi. Journ of Yeast and Fungal Res. 1:025-029.

Sajna, KV; Hofer, R; Sukumaran, RK; Gottumukkala, LD; Pandey, A (2015.white biotechnology in biosurfactants in industrial biorefineries \& white biotechnology, eds. A. Pandey, R. Hofer, M. Taherzadeh, M. Nampoothiri, and C. Larroche (Amsterdam: Elsevier). 499-521.

Uzoamaka, G; Floretta, T; Florence, M (2009). Hydrocarbon degradation potentials of indigenous fungal isolates from petroleum contaminated soils. J. Phy. Nat. Sci. 3(1):1-6.

Vecchioli, GL; Del Panno, MT; Painceira, MT (1990). Use of selected autochtonous soil bacteria to enhance degradation of hydrocarbons in soil. Environ. Poll. 67:249-258.
Xiaoxu, S; Joel, E (2019). Hydrocarbon-degrading microbial communities are site specific, and their activity is limited by synergies in temperature and nutrient availability in surface ocean waters. Appl. Environ. Microb. 85 (15): 443-19.

Zampolli, J; Collina, E; Lasagni, M; Di Gennaro, P (2014). Biodegradation of variable-chain-length n-alkanes in Rhodococcus opacus R7 and the involvement of an alkane hydroxylase system in the metabolism. AMB Exp. 4(1): 73.

Zhang, JH; Xue, QH; Gao, H; Ma, X; Wang, P (2016a). Degradation of crude oil by fungal enzyme preparations from Aspergillus spp. for potential use in enhanced oil recovery. J. Chem. Tech and Biotech. 91(4): 865-875.

Zhang, T; Wang, NF; Liu, HY; Zhang, WQ; Yu, LY (2016b). Soil pH is a key determinant of soil fungal community composition in the NyAlesund Region, Svalbard (High Artic). Front Micro. 7:227.

Zhang, MM; Wang, N; Hu, Y; Sun, G (2018). Changes in soil physicochemical properties and soil bacterial community in Mulberry (Morus alba)/alfalfa (Medicago sativa) intercropping system. Microb Open. 7(2):1-11. 